\title{
Management of the major pests of french bean through development and val- idation of certain IPM modules, Assam, India
}

\author{
D. Sharmah $^{1^{*}}$ and S. Rahman ${ }^{2}$ \\ ${ }^{1}$ Krishi Vigyan Kendra, ICAR, South Tripura-799 144 (Tripura), INDIA \\ ${ }^{2}$ Department of Entomology, Assam Agricultural University, Jorhat- 785013 (Assam), INDIA \\ *Corresponding author. E-mail: dasharmah@gmail.com
}

Received: July 14, 2016; Revised received: January 9, 2017; Accepted: April 7, 2017

\begin{abstract}
The present investigation was carried out in the ICR farm, Assam Agricultural University, Jorhat during 2013-14 and 2014-15 for management of the major pests through development and validation of certain IPM modules. Lesser per cent incidence of aphid (0.60\%) was seen in Module-I than Module-III (2.58 \%) and Module-II (6.0 $\%)$ and has significant at $5 \%$ probability level. But highest percentage of aphid incidence $(13.40 \%)$ was registered in Module-IV. The mean population of thrips varied from 1.0 to 10.0 per cent among the modules. Module-I was found to be superior by recording significantly less incidence of thrips (1.04\%) than Module-III (2.6 \%) and Module-II $(4.0 \%)$. Considerably higher per cent incidence of thrips was observed in Module-IV (10.0\%). The per cent population of mite was least (1.0\%) in Module-I compared to Module-III (3.0\%) and Module-II (7.6\%). Maximum incidence of mites was recorded in Module -IV (9.0\%). Whitefly incidence was recorded to be minimum $(1.2 \%$ in Module - I compared to Module-III (2.80 \%) and Module-II (4.0\%). The highest percent incidence of whitefly was registered in Module -IV (10.8\%). Module-I was found to be superior by recording significantly less incidence of pod borer $(0.40$ $\%)$ and was significantly differed from Module-III (3.2\%) and Module-II (5.8 \%). The highest healthy green bean yield ha ${ }^{-1}$ was achieved in Module-I (13.99 tha $^{-1}$ ) followed by Module-III $\left(13.91\right.$ tha $\left.^{-1}\right)$, Module-II $\left(13.56\right.$ tha $\left.^{-1}\right)$ and Module-IV (9.88 tha $\left.{ }^{-1}\right)$. The effectiveness of IPM Modules in respect to B:C ratio were obtained to be $2.06,1.95$ and 1.97 from Module-I, II and III respectively. The present experimental findings can be used as alternative for chemical pesticides at farmer's field and will certainly be reduce the detrimental effect of insecticides application.
\end{abstract}

Keywords: B:C ratio, Effectiveness, French bean, Insect pests, IPM modules, Management

\section{INTRODUCTION}

India is the largest producer and consumer of pulses in the world accounting for about 29 per cent of the world area and 19 per cent of the world's production. More importantly, India is also the largest importer and processor of pulses in the world. Ironically, the country's pulse production has been hovering around 14-15 MT, coming from a near-stagnated area of $22-23 \mathrm{M}$ ha, with average productivity $689 \mathrm{~kg} / \mathrm{ha}$ (Singh et al., 2015). French bean is grown mainly in the states of Jharkhand, Karnataka, Andhra Pradesh, Maharashtra, Tamil Nadu, Odisha, Bihar, Nagaland, Meghalaya, Sikkim, Mizoram, Jammu and Kashmir, Himachal Pradesh and West Bengal (Saxena et al., 2015). According to UN Food and Agriculture Organization (FAO, 2012), India is the third producer $(6,20,000$ MT) of this green bean after China (16,200,000 MT). In India, French bean covers an area of 137.54 thousand hectare with production of 1370.21 thousand tones and productivity of $478 \mathrm{~kg} \mathrm{ha}^{-1}$ (Saxena et al., 2015). Since it is a short duration (85-90 days) crop, it can very well fit as a component of intercropping and sequence cropping in many of the agro-climatic zones.
French bean is traditionally a crop of temperate region. It is cultivated in hilly tract of Jammu and Kashmir, Himachal Pradesh (Kullu, Barot, Chamba and Shimla valley) and Uttar Pradesh. While its cultivation is mainly restricted to hilly region of north India, its consumption is more in the plains of north and central India, where 'its demand is not fully met. It is grown in Jammu and Kashmir, Himachal Pradesh, Hills of Uttar Pradesh and in some parts of Maharastra (Mahabaleshwar and Ratnagiri region) as a kharif crop and in some other parts of Maharastra, Andhra Pradesh, western and eastern Ghats and north-east plains where winters are mild and frost free as a winter crop. Recently its cultivation has been extended to northern plain zone (Sardana et al., 2000). Chandra and Ali (1986) exploited the feasibility of growing rajmah as a potential rabi crop in the plains of north India.

Introduction of this non-traditional crop to north eastern plains of India as a winter crop has generated lot of interest in the farming community due to its higher productivity, responsiveness to inputs and remunerative price. French bean is quite nutritious and potential source of protein carbohydrates and minerals (Aykroyd and Doughty, 1973). During the last decades French 


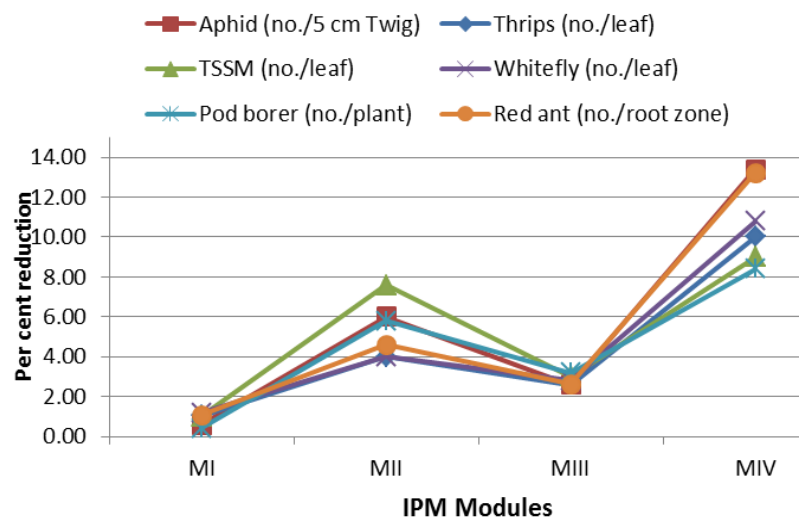

Fig. 1. Effect of IPM modules in reduction of french bean pests complex.

bean is becoming increasingly important as a cash crop in India. It has a large export potential (Abdel- Mawgoud et al., 2005). About 30 species of insects have been reported damaging French bean crop (Srivastava and Butani, 1998). Among the major pests reported elsewhere for beans are the bean seed fly (Delia platura), bean flies (Ophiomyia spp.), cutworms (Agrotis spp.), aphids (Aphis craccivora and A. fabae), leafminers (Liriomyza spp.), spider mites (Tetranychus spp.), whiteflies (Bemisia tabaci) and the African bollworm (Helicoverpa armigera) (Allen et al., 1996). Thrips are the most important pest of French beans at flowering and harvesting (Nderitu et al., 2010; Nyasani et al., $2012 \mathrm{~b}$ ). Losses of more than $60 \%$ have been reported on the marketable pods as a result of thrips damage (Nderitu et al., 2009). Two spotted spider mites attack French beans at seedling to maturity levels and Spider mite caused 10-15\% loss in vegetables (Ghoshal, 2013). Other pests that attack French beans at different growth stages include white flies, pod borers and leaf miners (Lohr, 2006).

Many insecticides have been recommended for the control of French bean insect and mite pests but these are known to cause mortality of natural enemies, residues problem, hazards to man and animal besides polluting the environment (Sharma et al., 2012). On several occasions, insecticidal application have accentuated the insect population and quite often resulted in outbreak (Aktar et al., 2009). Although chemical control has been effective for control of insect pests of French bean (Nderitu et al., 2008), various problems have arisen that include consumers' demand for produce that is not free from pesticide residues, resistance development, environment issues and safety of workers as well as animals (Nderitu et al., 2007; Nyasani et al., 2012a). The injudicious use of synthetic pesticides can lead to secondary outbreaks of pests that are normally under natural control resulting in their rapid proliferation. There have also been cases of pests becoming tolerant to insecticides, resulting in the use of double and triple application rates. In addition, due to other problems such as health hazards, undesirable
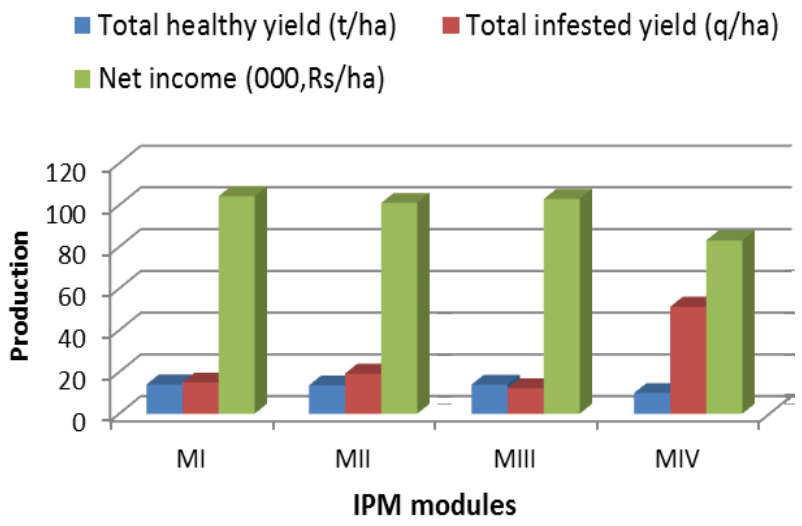

Fig. 2. Impact of IPM modules ongreen bean production and economic return in french bean.

side effects and environmental pollution caused by the continuous use of synthetic chemical pesticides (Nas, 2004), there is renewed interest in the use of IPM modules that are free from all undesirable effect of chemical insecticides applied for french bean crop protection. Keeping in view the present experiment was carried out to Development and Validation of certain IPM modules for Management of the major pests of French bean.

\section{MATERIALS AND METHODS}

Layout of the experiment: The experiment was conducted in Integrated Crop Research (ICR) farm of Assam Agricultural University, Jorhat, Assam. A total of four modules as treatments including control were arranged in a Randomized Block Design (RBD) with five replication in a gross area of $180.5 \mathrm{sqm}$ having individual plot size of $2 \mathrm{~m} \mathrm{X} 3 \mathrm{~m}$. The components of modules included

\section{Module I ( $\left.\mathbf{T}_{1}\right)$}

Seed treatment with Captan @3gm/kg seed Weeding frequency (3 times at 15 days interval)

Yellow sticky trap@20nos./haMechanical destruction (removing by hand picking and destroying them) Inter crop with Coriander (2:1 ratio)

Release of potential predators of aphid and TSS mite

\section{Module II ( $\left.\mathbf{T}_{2}\right)$}

Seed treatment with Captan @ 3gm/kg seed

Weeding frequency (3 times at 15 days interval)

Yellow sticky trap@20no./ha

Mechanical destruction (removing of infected leaves by hand picking and destruction)

Spraying with commercial neem formulation@3ml/ liter on incidence of pests.

Module III (Recommended practice) $\left(\mathbf{T}_{3}\right)$

Seed treatment with Captan @3gm/kg seed Spraying with Malathion@ 1-1.5litre in 800-1000 litre of water/ha. (2 sprays at 15days interval)

Module IV (Untreated control) $\left(\mathbf{T}_{4}\right)$

French bean (variety: Super fulguni) was sown on last week of October whereas coriander seeds were sown 
Table 1. Effect of different IPM modules on french bean pests complex.

\begin{tabular}{lcccccc}
\hline \multirow{2}{*}{ Treatment } & \multicolumn{7}{c}{ Insect and TSS mite pests incidence (\%) } \\
\cline { 2 - 7 } & Aphid & Thrips & TSSM & Red ant & Whitefly & Pod borer \\
\hline Module I $\left(\mathrm{T}_{1}\right)$ & $0.60^{\mathrm{d}}(0.77)$ & $1.04^{\mathrm{c}}(1.02)$ & $1.00^{\mathrm{c}}(1.00)$ & $1.08^{\mathrm{c}}(1.04)$ & $1.20^{\mathrm{c}}(1.10)$ & $0.40^{\mathrm{c}}(0.63)$ \\
Module II $\left(\mathrm{T}_{2}\right)$ & $6.00^{\mathrm{b}}(2.45)$ & $4.00^{\mathrm{b}}(2.00)$ & $7.60^{\mathrm{a}}(2.76)$ & $4.60^{\mathrm{b}}(2.14)$ & $4.00^{\mathrm{b}}(2.00)$ & $5.80^{\mathrm{a}}(2.41)$ \\
Module III $\left(\mathrm{T}_{3}\right)$ & $2.58^{\mathrm{c}}(1.61)$ & $2.60^{\mathrm{bc}}(1.61)$ & $3.00^{\mathrm{b}}(1.73)$ & $2.62^{\mathrm{bc}}(1.63)$ & $2.80^{\mathrm{bc}}(1.67)$ & $3.20^{\mathrm{b}}(1.79)$ \\
Module IV $\left(\mathrm{T}_{4}\right)$ & $13.40^{\mathrm{a}}(3.66)$ & $10.00^{\mathrm{a}}(3.16)$ & $9.00^{\mathrm{a}}(3.00)$ & $13.20^{\mathrm{a}}(3.62)$ & $10.80^{\mathrm{a}}(3.29)$ & $8.40^{\mathrm{a}}(2.90)$ \\
S.Ed & 0.31 & 0.29 & 0.25 & 0.29 & 0.28 & 0.26 \\
CD $(5 \%)$ & 0.67 & 0.63 & 0.54 & 0.63 & 0.63 & 0.56 \\
\hline
\end{tabular}

Data are pooled mean of two season trial with five replications, Figures in the same column with same letter(s) are not significantly different at $5 \%$ level as per LSD test, Figure in parentheses are square root transformed value.

Table 2. Impact of IPM modules in yield and economic returns of French bean.

\begin{tabular}{lllllllll}
\hline Treatment & $\begin{array}{l}\text { Total healthy } \\
\text { yield (t/ha) }\end{array}$ & $\begin{array}{l}\text { Total in- } \\
\text { fested yield } \\
\text { (t/ha) }\end{array}$ & $\begin{array}{l}\text { Gross Income } \\
(\mathbf{0 0 0 , R s / h a )}\end{array}$ & $\begin{array}{l}\text { Gross income } \\
\text { over } \\
\text { (000,Rs/ha) }\end{array}$ & $\begin{array}{l}\text { Total Cost of } \\
\text { production } \\
\text { (000,Rs/ha) }\end{array}$ & $\begin{array}{l}\text { Net } \\
\text { turn } \\
\text { Rs./ha) }\end{array}$ & $\begin{array}{c}\text { Re- } \\
(\mathbf{0 0 0},\end{array}$ & $\begin{array}{l}\text { B:C } \\
\text { ratio }\end{array}$ \\
\hline $\mathrm{M}_{\mathrm{I}}$ & $13.99^{\mathrm{a}}(3.74)$ & $1.49^{\mathrm{a}}(1.22)$ & $139.88^{\mathrm{a}}(11.82)$ & 41.08 & 35.67 & 104.21 & 2.06 \\
$\mathrm{M}_{\mathrm{II}}$ & $13.56^{\mathrm{b}}(3.68)$ & $1.92^{\mathrm{b}}(1.38)$ & $135.63^{\mathrm{b}}(11.63)$ & 36.79 & 34.63 & 100.97 & 1.95 \\
$\mathrm{M}_{\mathrm{III}}$ & $13.91^{\mathrm{a}}(3.73)$ & $1.21^{\mathrm{a}}(1.10)$ & $139.07^{\mathrm{a}}(11.79)$ & 40.26 & 36.21 & 102.86 & 1.97 \\
$\mathrm{M}_{\mathrm{IV}}$ & $9.88^{\mathrm{c}}(3.14)$ & $5.12^{\mathrm{c}}(2.24)$ & $98.81^{\mathrm{c}}(9.93)$ & 0.00 & 15.67 & 83.05 & - \\
$\mathrm{S} . \mathrm{Ed}$ & 0.08 & 0.14 & 0.31 & - & - & - & - \\
$\mathrm{CD}(5 \%)$ & 0.17 & 0.30 & 0.69 & - & - & - & - \\
\hline
\end{tabular}

Data are mean of five replications, Figures in the same column with same letter(s) are not significantly different at $5 \%$ level as per LSD test, Figure in parentheses are square root transformed value.

in first week of November during 2013-14 and 201415 , respectively in Module-I $\left(\mathrm{T}_{1}\right)$. The incidence of insect and mite pests was recorded from every plot including replicated plot of each IPM module. Each plant was carefully examined at morning 8-10 O'clock and every week at regular interval starting from 15 days after sowing. To evaluate the effectiveness of the tested modules, percent reduction of insect and mite pests was calculated according to Henderson and Tilton (1955) formula.

Observations: All observation was made on 10 randomly selected tagged plants per plot. Effect of IPM modules on population of aphid (no. $/ 5 \mathrm{~cm}$ twig), thrips (no./leaf), two spotted spider mite (no./leaf), whitefly (no./leaf) and pod borer and cutworm (no/plant) infestation starting from 15 days after germination till harvest was considered on already selected and tagged plants.For the economics of IPM modules, yield of individual plot was taken separately and mean was calculated accordingly for each IPM module and B : C Ratio was determined.

Cost: Benefit ratio of tested IPM modules was calculated by using the below mentioned formula:

B: $\mathbf{C}$ ratio $=$ Gross return $(000$ ' Rs. $/$ ha) over control $/$ Total cost of plant protection over control (000, Rs./ha) Intercrop coriander: Coriander (Coriandrum sativum L.) is an aromatic herb, cultivated as a summer or a winter annual crop, depending on the climatic conditions (Kofidis et al., 2008). This pungent herb is native of southern Europe and is commonly known as Coriander, Cilantro, or Chinese parsley. The leaves of coriander are light green, feathery, and flat. The distinctive flavour of coriander leaves is quite different from that of parsley. While the leaves are used as a herb, the dried seeds, called coriander seeds, are used as a spice and have an entirely different taste.

Aphid culture under laboratory condition: French bean crop was sown in well prepared pot@2 seed per pot one month before the sowing of main crop in the field. Ten numbers of such pots were maintained under laboratory condition for continuous supply of Aphis craccivora as food to coccinelid predator. The aphid colony was established by collecting aphid, A. craccivora L. from a infested bean field of ICR farm, AAU, Jorhat in summer 2013-14 and re-established in 2014-15 from same field. The colony was perpetuated by regularly infesting two week old potted french bean plants under laboratory condition.

Laboratory rearing of Coccinnela transversalis: The standard mass rearing technique for the coccinellid predators as described by Soni et al. (2008) was adopted. For this some males and females of the C. transversalis were collected by sweep net from the unsprayed fields of ICR Farm, Assam Agricultural University, Jorhat and were confined in the wooden famed net cage $(55 \times 55 \times 61 \mathrm{~cm})$ for egg laying. C. transversalis were reared at the Acarology laboratory, Department of Entomology, AAU, Jorhat, Assam, in wooden framed net cage and different life stages were handled separately. The adult were feed with bean aphid (Aphis craccivora) (already reared in laboratory) at regular interval till egg laying. Laid eggs were collected every 1 to 2 day and placed in holding containers and individual clutches were transferred when their eggs began to hatch. Neonate larvae were transferred to 3.5 -liter cages $(8 \times 8 \times 9 \mathrm{~cm})$ containing 
A. craccivora (L.) as prey, and 3 to 4 days later second instars were transferred to analogous cages containing aphids as prey. Third and fourth in stars were reared individually in small container provided with aphids. Pre pupae and pupae were transferred to fresh container and collectively placed in cages. Newly emerged adults were collected from the cages about 2 days after eclosion. Adults were housed in cages stocked with aphids. Details followed regarding the rearing of aphid prey and procedures used to rear coccinellidbeetles during specific life stages. Large quiescent fourth instars (i.e. pre-pupae) had typically settled on french bean leaves or their holding containers. Individual prepupae/pupae, and cups and lids with attached individuals were carefully transferred to a new holding container for the duration of pupation. Finally, a large number of coccinellid adult was emerged and became ready for field release.

Statistical analysis: The experiment was conducted in Randomized Block Design (RBD) with five replications and data were analyzed by following Analysis of Variance (ANOVA). Statistical package Minitab 16.0 was used for all the statistical analyses and means were separated using Least Significance Difference (LSD) based Minitab16 computer programme.

\section{RESULTS AND DISCUSSION}

Experimental findings on effect of IPM modules on incidence and economic returns are presented below mentioned subhead (Table 1 and 2 and Fig. 1 and 2).

Effect of IPM modules on incidence: Data presented in table 1 and fig. 1 indicated that, lesser per cent incidence of Aphis craccivora was seen in Module-I $(0.60 \%)$ than Module-II (6.0 \%) and Module-III (2.58 $\%$ ) and differed significantly at $5 \%$ probability level. But highest percentage of aphid incidence $(13.40 \%)$ was registered in Module-IV. The mean population of thrips varied from 1.04 to 10.0 per cent among the modules. Module-I was found to be superior by recording least incidences of thrips $(1.04 \%)$ than Module -II (4.0\%) and Module-III (2.6\%). Considerably higher per cent incidence of thrips was observed in Module-IV (10.0\%). The per cent population of TSSM was least $(1.0 \%)$ in Module-I compared to Module -II (7.6 \%) and Module-III (3.0 \%). However, maximum incidence of mites was recorded in Module -IV $(9.0 \%)$. Whitefly incidence was recorded to be minimum in Module -I (1.2\%) compared to Module III $(2.80 \%)$ and Module -II $(4.0 \%)$. While highest percent incidence of whitefly was registered in Module -IV $(10.8 \%)$. The mean per cent population of pod borer varied from 0.40 to $8.40 \%$ among the different modules. Module-I was found to be superior by recording less incidence of pod borer $(0.40 \%)$ and was significantly $(\mathrm{P}=0.05)$ differed from Module -IV (8.4\%) (Table 1 and Fig. 1).

This result is in conformity with the findings of Rizk,
2000 and Abo-Shanab et al., 2012 who reported that coriander intercropping with tomato decreases pest attack in Fayoum, Egypt and Nubariya, Egypt respectively. The present result is also supported by the several findings that intercropping method gave good results when wheat intercropping with clover (Ghabbour et al., 1994); using tomato intercropping with faba-bean, and tomato intercropping with lupinus (Rizk and Mikhail, 2000) and reduce injury from sucking pests. Various explanations have been given for the changes in pest populations under different intercropping systems. Insect population reductions have been generally attributed to disruption of the insect's visual and olfactory responses (Taylor, 1977; Jackai et al., 1985; Giga and Munetsi, 1989; Rizk, 2000). This may be due to that companion and neighboring plants can reduce pest pressure by providing habitat for the pest's enemies, confuse pests and camouflage crops, trap pests and repel pests, Wallace (2013). The advantages concluded higher income per unit area than sole cropping, acts as an insurance against failure of one crop in abnormal season, maintains soil fertility as the nutrient uptake is made from both layers, reduces soil runoff and helps in pest's control. Also, Karel et al. (1985) commented that infestation with whitefly, aphids, and spider mite decreased gradually when the space of intercropping being narrower and methods of cultivation which increase the density of plants will appreciably aid in reducing insect damage. The use of predator of aphid and mite as one of the component of the module $\mathrm{M}_{\mathrm{II}}$ also leads to reduction of these pests. It has been shown that Coccinellid beetle have a major role in reducing the pea aphid populations in alfalfa fields that was conducted in Hamedan, Iran (Soleimani and Hossein, 2015). The findings of Jakhar and Chaudhary (2013) is in conformity with the present finding that Coccinellid beetle had a significant positive relation in reducing aphids and mite population in Gujarat, India.

Effect of IPM modules in economic returns: Data on yield of French bean were collected and economic return was calculated for each IPM module and results are presented below:

The resultant data indicated that yield due to different IPM modules has great influenced and highest yield (15.48t/ha) (including both healthy and infested) was recorded in $\mathrm{M}_{\mathrm{I}}$ followed by $\mathrm{M}_{\mathrm{II}}(15.45 \mathrm{t} / \mathrm{ha})$ and $\mathrm{M}_{\mathrm{III}}$ (15.12t/ha). However, least yield (15.0t/ha) was registered in $\mathrm{M}_{\mathrm{IV}}$ (Table 2 and figure 2$)$.

Total healthy yield, total infested yield and gross return were significantly $(p=0.05)$ influenced by different IPM modules (Table 2). Results indicated that the highest healthy bean yield $\mathrm{ha}^{-1}\left(13.99 \mathrm{t} \mathrm{ha}^{-1}\right)$ was achieved due to effect of $M_{I}$ which was significantly different from all other treatments followed by $\mathrm{M}_{\text {III }}$ $\left(13.91 \mathrm{t} \mathrm{ha}^{-1}\right)$. On the contrary, the lowest healthy bean yield $\left(9.88 \mathrm{tha}^{-1}\right)$ was obtained from control treatment 
$\left(\mathrm{M}_{\mathrm{IV}}\right)$. The lowest infested bean yield ha-1 (1.21t ha $\left.\mathrm{a}^{-1}\right)$ was found due to the effect of $\mathrm{M}_{\mathrm{III}}$ which differed from all other treatments followed by $\mathrm{M}_{\mathrm{I}}\left(1.49 \mathrm{t} \mathrm{ha}^{-1}\right)$. Furthermore, the highest infested bean yield ha ${ }^{-1}(5.12 \mathrm{t} \mathrm{ha}$ ${ }^{1}$ ) was obtained from control treatment $\left(\mathrm{M}_{\mathrm{IV}}\right)$. The IPM modules caused effective pest management in French bean crop and have a great gross return. In the present study, applied IPM modules showed variable performance for managing the insect pests of French bean (Table 1). The effectiveness of IPM modules was not same but varied significantly and this is why a great variation was occurred in terms of gross return. Results showed that the highest gross return $(000$, Rs. 41.08 ha ${ }^{-1}$ ) over control was achieved from $\mathrm{M}_{\mathrm{I}}$, whereas the lowest gross return $\left(000\right.$, Rs. $\left.36.79 \mathrm{ha}^{-1}\right)$ over control came from module $\mathrm{M}_{\mathrm{II}}$. The second highest gross return (000, Rs. $\left.40.26 \mathrm{ha}^{-1}\right)$ over control was observed in $\mathrm{M}_{\mathrm{III}}$ which was close to $\mathrm{M}_{\mathrm{I}}$. Under the treated plot, the lowest gross return $\left(000\right.$, Rs. $\left.36.79 \mathrm{ha}^{-1}\right)$ was observed from $\mathrm{M}_{\mathrm{II}}$. The effectiveness of IPM Modules in respect to $\mathrm{B}$ : $\mathrm{C}$ ratio were obtained to be $2.06,1.95$ and 1.97 from Module - I, II and III respectively as compared to control.Evaluation of red gram (pigeon pea) Integrated Pest Management (IPM) module in comparison with the farmers' practice conducted at National Pulses Research Centre (NPRC), Tamil Nadu registered reduced pod borer damage $(31.5-35.67 \%)$ as against the farmer's practice pod borer damage (48.67 - 54.67\%). The grain yield $(714-801 \mathrm{~kg} / \mathrm{ha})$ and Benefit: Cost (2.41-2.79) were also higher in IPM module application plots compared to farmer's practice (Srinivasan and Sridhar, 2008) that support the present findings. Rao and Reddy (2003) also recorded higher grain yields from the IPM modules in pigeonpea and C: B ratio of 1: 9 conducted at Rajendranagar, Hyderabadthat confirmed the present findings. Similarly, the present finding is in conformity with the result of Gajendran et al. (2006) where they observed higher grain yield of pigeonpea $\left(530 \mathrm{~kg} \mathrm{ha}^{-1}\right)$ and more $\mathrm{C}$ : B ratio $(1.73)$ in IPM fields than in normal practice (410 kg ha $\left.{ }^{-1}\right)$.

\section{Conclusion}

A total of four IPM modules including the control treatment were tested against major insect and mite pests of French bean and out of which IPM module -I with seed treatment by Captan @ 3gm/ kg seed, weeding frequency ( 3 times at 15 days interval), yellow sticky trap@20nos./ha, mechanical destruction (removing by hand picking and destroying them), inter crop with coriander (2:1 ratio), release of $C$. transversalis of aphid and TSSM was found to be most effective as compared to the other IPM modules tested. The IPM modules in respect to $\mathrm{B}$ : $\mathrm{C}$ ratio were obtained to be 2.06 in IPM module-I and was found to be best against insect pests of French bean, hence, this IPM module may be recommended against insect and mite pests of French bean as alternative of non-judicial application of chemical insecticides. The present experimental findings can be a component of organic cultivation of French bean crop.

\section{REFERENCES}

Abdel-Mawgoud, A.M.R., El- Desuki. M., Salman, S. R. and Abo-Hussein, S. D. (2005). Performance of some snap bean varieties as affected by different levels of mineral fertilizers. Journal of Agronomy, 4(3): 242-247

Abo-Shanab, A.S.H., Moursi, K.S. and Hussein, H.S. (2012). Effect of intercropping of Coriander (Coriandrum sativum L.) with Tomato (Solanum lycopersicum) on sucking pests management infesting tomato. In Nubariya, El-Bheira Governorate, Egypt

Aktar, W., Sengupta, D. and Chowdhury, A. (2009). Impact of pesticides use in agriculture: their benefi its and hazards. Interdiscipl Toxicol, 2: 1-12

Allen, D.J., Ampofo, J.K.O. and Wortmann, C.S. (1996). Pests, diseases and nutritional disorders of the common bean in Africa. A field Guide. A CIAT/CTA publication, (ISBN: 958943955 1)

Aykroyd, W.R. and Doughty, J. (1973). Food Agricultural Organisation (FAO), Nutrition Studies No. 19

Chandra, S. and Ali, M. (1986). Technical Bulletin No.1. Directorate of Pulses Research, Kanpur Pp.14-15

FAO, (2012). Food and Agricultural Organisation of the United Nations (FAOSTAT) website. Available at: http://faostat.fao.org/default.aspx

Gajendran, G., Chandrasekaran, M. and Jebaraj, S. (2006). Evaluation of integrated pest management module against major pests of blackgram in rainfed ecosystem. Legume Research, 29: 53-56

Ghabbour, S. I., Rizk, M. A. and Mikhail, W. Z. A. (1994). Multivariate analysis of pest incidence in play culture agro-eco-system in Fayoum, Egypt. Proceedings of the international Meeting "Ecology and Statistical Methods". Niort (France), 5-6 October: 207-214

Ghoshal, S. (2013). Population dynamics and biochemical fluctuations in relation to the infestation of tetranychus neocaledonichus andre on the leaves of Tulsi (Ocimum sanctum). International Journal of Life Science Biotechnology \& Pharm Reseach., 2(3): 225-231

Giga, D. P. and Munetsi, M. (1989). The effect of intercropping maize and cow peas on insect pest population. African Agriculture Journal, 54 (3): 147-152

Henderson, C. F. and Tilton, E. W. (1955). Tests with acaricides against the brown wheat mite. Journal of Economic Entomology, 48: 157-161

Jackai, L.E.N., Singh, S.32R., Roheja, A. K. and Wiedijk, F. (1985). Recent trends in the control of cowpea pests in Africa, in: cowpea Research, pramluetion. Utilization edts. S. R. Singh and K. O. Rachia. John Wiley and Sons Pp. 233-243

Jakhar, B. L. and Chaudhary, F. K. (2013). Influence of abiotic Factors on Incidence of sucking pest in French bean. AGRES, 2(1): 68-71

Karel, A. K., Lakllan, D. A. and Udunguru, B. J. (1985). Intercropping maize and cowpea. Effect of plant population on insect pests and seed yield, in: Intercropping, Proc. 2nd Symp. Intercropping Semi Arid Area, Morgora, Tanzouns Pp. 4-7

Kofidis, G., Giannakoula, A. and Ilias, F. (2008). Growth, 
anatomy and chlorophyll fluorescence of coriander plants (Coriandrum sativum L.) treated with 7 prohexadione-calcium and daminozide, Polish Academy of Sciences, Cracow. Acta Biologica Cracoviensia Series Botanica, 50(2): 55-62

Lohr, B. (2006). High value crops research and development: The ICIPE experience. International Centre of Insect Physiology and Ecology, Nairobi, Kenya

Nas, M. N. (2004). In vitro studies on some natural beverages as botanical pesticides against Erwinia amylovora and Curobacterium flaccumfaciensis subsp. poinsettiae. Turkis Journal of Agriculture, 28: 57-61

Nderitu, J.H., Wambua, E.M., Olubayo, F., Kasina, J.M. and Waturu, C.N. (2007). Management of thrips (Thysanoptera: Thripidae) Infestation on French beans (Phaseolus vulgaris L.) in Kenya by Combination of insecticides and Varietal resistance. Journal of Entomology, 4: 469-473

Nderitu, J. H., Kasina, M. J., Nyamasyo, G. N., Waturu, C. N. and Aura, J. (2008). Management of Thrips (Thysanoptera: Thripidae) on French Beans (Fabaceae) in Kenya: Economics of Insecticide Applications. Journal of Entomology, 5: 148-155

Nderitu, J., Mwangi, F., Nyamasyo, G. and Kasina, M. (2009). Evaluation of cropping systems as a strategy for managing snap bean flower thrips in Kenya. International Journal of Sustainable Crop Production, 4(6): $22-25$

Nderitu, J. H., Mwangi, F., Nyamasyo, G. and Kasina, M. (2010). Utilization of synthetic and botanical insecticides to manage thrips (Thysan.: Thrip.) on snap beans (Fabaceae) in Kenya. International Journal of Sustainable Crop Production, 5(1):1-4

Nyasani, J. O., Meyhofer, R., Subramanian, S. and Poehling, H. M. (2012a). Effect of intercrops on thrips species composition and population abundance on French beans in Kenya. Entomologia Experimentalis et Applicata, 142: 236-246

Nyasani, J. O., Meyhofer, R., Subramanian, S. and Poehling, H. M.(2012b). Feeding and oviposition preference of Frankliniella occidentalis for crops and weeds in Kenyan French beans fields. Journal of applied Entomology, 137: 204-213

Rao, M. S. and Reddy, K. D. (2003). IPM of pod borers in long duration pigeonpea. Annual Plant Protection Science, $1: 26-30$

Rizk, M. A. (2000). The effect of certain medicinal plants (Coriander) intercropping with tomato in reducing pest infestation in Fayoum, Egypt. Proceeding of the $8^{\text {th }}$
Egyptian Conference on medicinal and aromatic plants and the Effect of Intercropping of (Guar) Leguminosae (Cyompois tetragonolaba) with Tomato on Level Infestation of Sucking Millennium 21-22 Nov. Pp. $132-152$

Rizk, M. A. and Mikhail, W. Z. A. (2000). Relationship of irrigation regimes and intercropping with pest infestation of tomato in Fayoum, Egypt Journal ofZoology, 35: 361-371

Sardana, V., Dhingrae, K.K., Gille, M.S. and Singh, I.J. (2000). Production Technology of French bean (Phaseolus vulgaris L) Cultivation: A Review. Agrlc. Rev., 21(3): 141-154

Saxena, M., Bhatacharya S. and Malhotra, S.K . (2015). Horticulture Statistics at a Glance, Oxford University Press, New Delhi

Sharma, D. R., Thapa, R. B., Manandhar, H. K., Shresth, S. M. and Pradhan, S. B. (2012). Use of pesticides in Nepal and impacts on human health and environment. $J$ Agric Environ, 13: 67-72

Singh, A.K., Singh, S.S., Prakash, V., Kumar S. and Dwived, S. K. (2015). Pulses Production in India: Present Status, Bottleneck and Way Forward. Journal of Agri Search, 2(2): 75-83

Soleimani, S. and Hossein, M. (2015). Seasonal dynamics of: the pea aphid, Acyrthosiphon pisum (Harris), its natural enemies the seven spotted lady beetle Coccinella septempunctata, Linn. and variegated lady beetle Hippodamia variegata Goeze, and their parasitoid Dinocampus coccinellae (Schrank). Journal of Plant Protection Research, 55(4): 421-428

Soni, R., Deol, G.S. and Brar, K. S. (2008). Feeding potential of Coccinella septempunctata Linnaeus on wheat aphid complex in response to level/intensity of food. Journal of Insect Science, 21(1): 90-92

Srivastava, K. P. and Butani, D. K. (1998). Pest management in vegetables (Part-I), Published by Research Periodicals and Book Publishing House, P.O. Box 720728, Houston, Texas-77272, USA

Srinivasan, G. and Sridhar, R. P. (2008). Evaluation of Integrated Pest Management Module against major pests of rainfed pigeon pea, Legume Research-An International Journal, 31(1): $60-62$

Taylor, T. A. (1977). Mixed cropping as an input in the management of crop pests in tropical Africa. African Environment, 2: 111-126

Wallace, J. (2013). Organic Agriculture Centre of Canada (OACC). http://www.organicagcentre. ca/tcog_ planting_pest_control.asp 